\title{
Spine Examination during COVID-19 Pandemic via Video Consultation
}

\section{Telemedizinische Wirbelsäulenuntersuchung während der COVID-19-Pandemie}

Authors

Tom Jansen ${ }^{1}$, Martin Gathen ${ }^{1}{ }^{\mathbb{D}}$, Amadeo Touet ${ }^{1}$, Hans Goost ${ }^{2}$, Dieter Christian Wirtz ${ }^{1}$, Christof Burger ${ }^{1}$, Robert Pflugmacher ${ }^{1}$, Kristian Welle ${ }^{1}$, Koroush Kabir ${ }^{1}$ (D)

Affiliations

1 Department of Orthopaedics and Trauma Surgery, University Hospital Bonn, Germany

2 Department of Orthopaedics and Trauma Surgery, Wermelskirchen Hospital, Germany

Key words

spine examination, COVID-19, telemedicine, video consultation, back pain

\section{Schlüsselwörter}

Untersuchung Wirbelsäule, COVID-19, Telemedizin, Videosprechstunde, Rückenschmerz

published online $\quad 02.02 .2021$

Bibliography

Z Orthop Unfall 2021; 159: 193-201

DOI 10.1055/a-1283-7160

ISSN 1864-6697

(C) 2021. Thieme. All rights reserved.

Georg Thieme Verlag KG, Rüdigerstraße 14,

70469 Stuttgart, Germany

Correspondence

PD Dr. med. Koroush Kabir

Klinik und Poliklinik für Orthopädie und Unfallchirurgie, Universitätsklinikum Bonn

Venusberg-Campus 1, 53105 Bonn, Deutschland

koroushkabir@yahoo.com

\section{ABSTRACT}

Introduction During the current COVID-19 pandemic video consultations are increasingly common in order to minimize the risk of infection for staff and patients. The aim of this study was to evaluate the feasibility of a spine examination via video.

Methods A total of 43 patients were recruited. Each participant underwent a video-based (VB) and a conventional faceto-face (FTF) spine examination. Pain intensity, active range of motion, inspection, a neurophysiologic basic exam and prov- ocations tests were evaluated using video-based and face-toface methods.

Results The intra-rater reliability (IRR) was measured between both examinations. Good to very good IRR values were obtained in inspection (Kappa between 0,752 und 0,944), active range of motion and basic neurophysiological examination (Kappa between 0,659 und 0,969). Only moderate matches were found in specific provocation tests (Kappa between 0,407 und 0,938 ). A video-based spine examination is a reliable tool for measuring pain intensity, active range of motion and a basic neurophysiologic exam.

Conclusion A basic spine examination during a video consultation is possible. A good agreement of the test results between video-based and face-to-face examination could be found.

\section{ZUSAMMENFASSUNG}

Einleitung Während der aktuellen COVID-19-Pandemie sind Videosprechstunden zur Kontaktvermeidung zunehmend verbreitet. Die vorliegende Studie soll die Machbarkeit einer Wirbelsäulenuntersuchung im Rahmen einer Videosprechstunde evaluieren.

Methoden Es wurden 43 Patienten in unserer Klinikambulanz untersucht. Die Patienten wurden zunächst videogestützt und unmittelbar später mit direkten Arzt-Patienten-Kontakt untersucht. Zur Strukturierung der Untersuchungsergebnisse wurde bei allen Untersuchungen ein systematischer Frageund Untersuchungsbogen verwendet. Gemessen wurde die Intrarater-Reliabilität (IRR) zwischen beiden Untersuchungsdurchgängen.

Ergebnisse Gute bis sehr gute IRR-Werte ergaben sich bei Inspektion (Kappa zwischen 0,752 und 0,944), Bewegungsausmaßen und neurophysiologischer Basisuntersuchung (Kappa zwischen 0,659 und 0,969). Nur moderate Übereinstimmungen konnten bei spezifischen Provokationstests (Kappa zwischen 0,407 und 0,938 ) gefunden werden.

Schlussfolgerung Eine Basisuntersuchung der Wirbelsäule ist im Rahmen einer Videosprechstunde möglich. Es konnte eine gute Übereinstimmung der Testergebnisse zwischen videogestützter und direkter Arztuntersuchung gefunden werden. 


\section{Background and Objective}

The back is the commonest location of musculoskeletal pain [1]. According to the most recent Global Burden of Disease report, diseases of the musculoskeletal system contribute most to global invalidity, while low back pain is the most common cause of incapacity for work [2]. The lifetime prevalence of back pain in the German adult population is $85.5 \%$ [3]. Back pain is therefore extremely important medically and economically and often requires outpatient or inpatient treatment.

Because of the COVID-19 pandemic, contact restrictions ("social distancing") and quarantine measures have become the new normal. Patients increasingly avoid visiting doctors in their practices or hospitals for fear of becoming infected [4]. Telemedicine has the potential to enable specialist medical consultation, at the same time minimising the risk of exposure to SARS-CoV2 [5]. There is therefore an increasing focus on telemedicine instruments such as video consultations. Previous studies have already described the general potential of telemedicine [6]. This certainly applies especially in disaster and infection prevention scenarios [7]. With the widespread use of smartphones, tablets, computers and commercial video consultation providers, the necessary technical equipment is available almost everywhere [8]. Previous studies have shown that video consultation can be used successfully for postoperative wound review or to discuss radiological results [9].

Nevertheless, to date there are no recommendations or guidelines regarding video-assisted examination of patients with back pain using telemedicine. The aim of this study is to address the feasibility and practicability of clinical examination of the spine in a video consultation during the ongoing COVID-19 pandemic.

\section{Study Design and Investigation Methods}

Patients with spinal complaints were examined once in a video consultation and then during a direct face-to-face medical consultation. For the study, the first video-assisted examination took place in an examination room in a university hospital outpatient clinic without assistance by relatives or medical staff. The examiner was in the next room at the same time.

Directly following the first video-assisted examination, the patient was examined again face-to-face. To limit the study to examining the feasibility and to avoid intra-observer variability, both examinations were performed by the same doctor. Two specialists in orthopaedics and trauma surgery carried out the examinations.

\section{Technical equipment}

The examiner used the usual standard setup for a video consultation (HP Elitedesk desktop computer, Logitech C270 webcam, Logitech $\mathrm{H} 390$ head-set).

The video consultation provider used in the study was arztkonsultation ak $\mathrm{GmbH}$ (Schwerin, Germany). We used the "Angle Meter 360" application (developed by Alexey Kozlov) to measure the active range of motion (AROM) ( $\vee$ Fig. 1 ). The subjects used a tablet with integrated camera and microphone (Apple, iPad Air 2) for transmission to the examiner in real-time.

\section{Collected data}

A systematic question and answer form was used at all examinations to structure the results ( $\bullet$ Fig. 2). This contains multiplechoice questions on inspection, pain location, pain severity, range of motion, provocation tests and a basic neurophysiological examination. In the video consultation the provocation tests were modified so that they could be performed by the patient on his own. The Lasegue, reverse Lasegue, Lhermitte, Adams and intervertebral cervical spine compression tests were performed.

Grading of the power of the key muscle in the basic neurophysiological examination was in only three levels (full power, against gravity and paresis) instead of the usual Janda five-point scale. For a rough assessment of power in the upper limb, the patient was provided with an ordinary plastic bottle (1.5 I PET) filled with water.

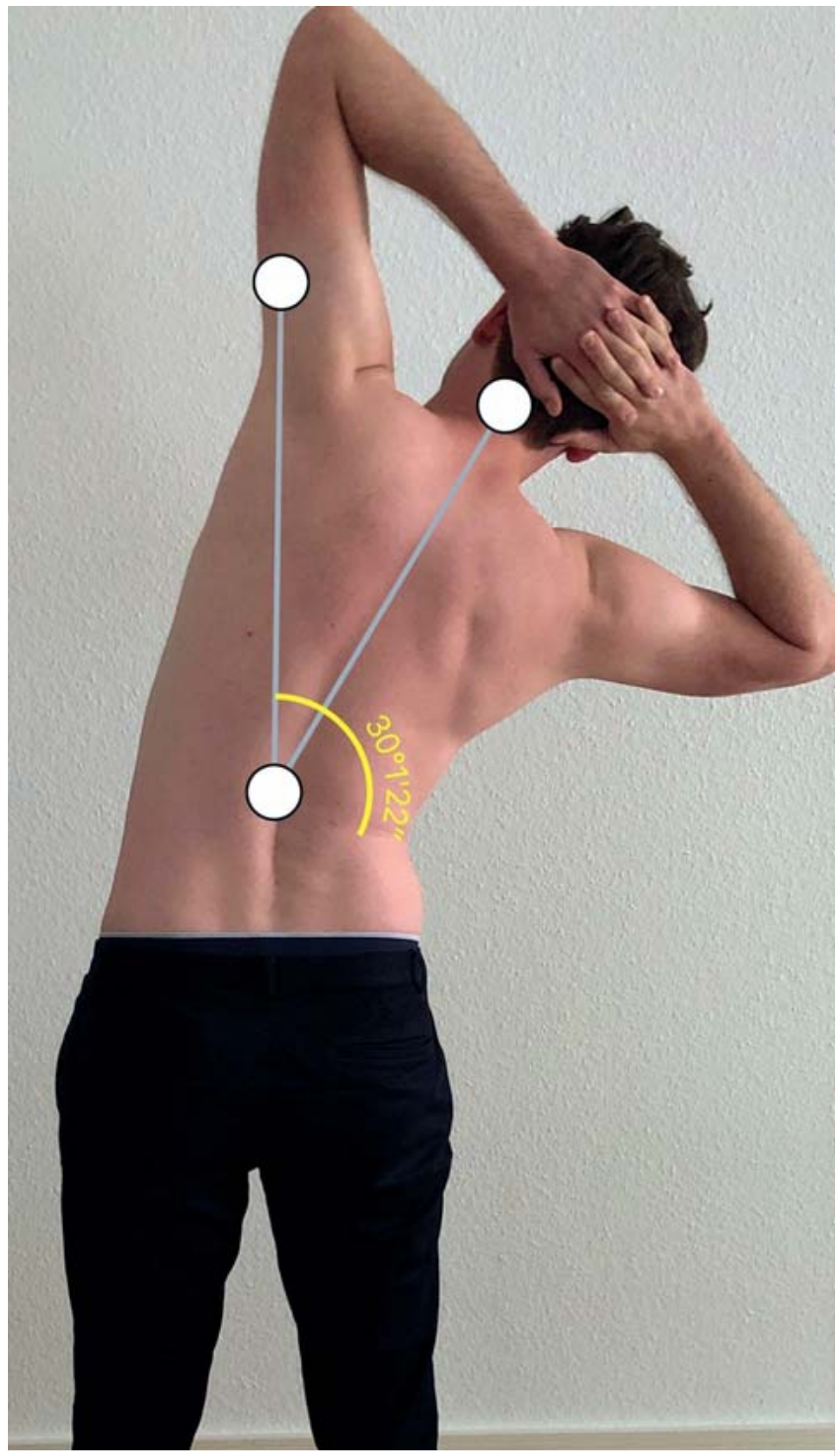

- Fig. 1 Measurement of the active range of motion via the "Angle Meter 360" application. 


\begin{tabular}{|c|c|c|c|c|c|c|c|c|c|}
\hline \multicolumn{10}{|c|}{ Wirbelsäulenuntersuchungsleitfaden Videosprechstunde } \\
\hline \multicolumn{2}{|l|}{ Nachname: } & \multicolumn{3}{|c|}{ Vorname: } & \multicolumn{5}{|l|}{ Geburtsdatum: } \\
\hline \multicolumn{10}{|l|}{ Inspektion Gangbild } \\
\hline Gangbild & \multicolumn{3}{|c|}{ 口Flüssig + frei } & $\begin{array}{l}\text { Nachyorne sebsugtes. } \\
\text { Gaobbild }\end{array}$ & $\begin{array}{l}\square \text { Nur an } \\
\text { UAGs/Rollator } \\
\text { mōgl. }\end{array}$ & $\begin{array}{l}\text { DUnsicheres } \\
\text { Gangbild }\end{array}$ & $\begin{array}{l}\text { 口Nicht } \\
\text { möglich }\end{array}$ & \multicolumn{2}{|l|}{ 口N.B. } \\
\hline $\begin{array}{l}\text { Inspektion von dorsal } \\
\text { (Mehrfachnennungen mōgl.) }\end{array}$ & \multicolumn{3}{|c|}{$\square$ Schulter- und Beckengeradstand } & \begin{tabular}{|l|} 
QSchulter- oder \\
Beckenschiefstand oder \\
Taillendreieckasymmetrie
\end{tabular} & \multicolumn{2}{|c|}{ 口 Tannenbaumphänomen } & \multicolumn{3}{|l|}{ 口N.B. } \\
\hline $\begin{array}{l}\text { Iofektzeischen (Hautrötung. } \\
\text { Schwellung) }\end{array}$ & \multicolumn{3}{|l|}{ 口נa } & $\square$ Nein & \multicolumn{5}{|l|}{$\square$ N.B. } \\
\hline $\begin{array}{l}\text { Auffälligkeiten Wunde/Narbe } \\
\text { (Mehrfachnennungen mögl.) }\end{array}$ & \multicolumn{3}{|c|}{$\square$ Keine Wunde/Narbe } & $\begin{array}{l}\text { Keine Auffalligkeiten } \\
\text { der Wunde/Narbe }\end{array}$ & $\begin{array}{l}\text { 口Wundsekret } \\
\text { klar/serös }\end{array}$ & $\begin{array}{l}\square \text { Wundsekret } \\
\text { trüb/eitrig }\end{array}$ & 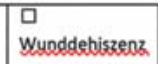 & $\square$ V.a. Fistel & 口Q d.8. \\
\hline Inspektion von lateral & \multicolumn{3}{|c|}{$\begin{array}{l}\text { Physiolog. Brustkyphose und } \\
\text { Lendenlordose }\end{array}$} & \begin{tabular}{|l|} 
vermehrte \\
Brustkyphose
\end{tabular} & $\begin{array}{l}\text { vermehrte } \\
\text { Lendenlordose }\end{array}$ & \multicolumn{4}{|l|}{$\square N . B}$. \\
\hline $\begin{array}{l}\text { Schmerzlokalisation } \\
\text { (Mehrfachnennung mögl.) }\end{array}$ & \multicolumn{3}{|l|}{ 口HWS } & $\square$ Bws & $\square$ LWS/ISG & \multicolumn{4}{|l|}{$\square$ Q D. } \\
\hline $\begin{array}{l}\text { Schmerzlokalisation } \\
\text { einzeichnen }\end{array}$ & 新 & \multicolumn{2}{|c|}{ 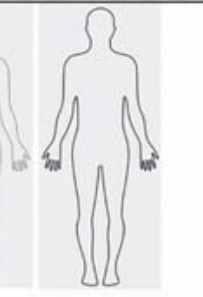 } & & \multicolumn{5}{|c|}{$\begin{array}{l}\text { Numerical Analogue Scale (NRS) } \\
\text { (0-10, 0= kein Schmerz, 10=stärks } \\
\text { Nackenschmerz: } \\
\text { Armschmerz: } \\
\text { Rûckenschmerz: } \\
\text { Beinschmerz: }\end{array}$} \\
\hline
\end{tabular}

\begin{tabular}{|c|c|c|c|c|c|c|c|}
\hline \multicolumn{8}{|l|}{ Funktion HWS } \\
\hline Aktive In-und Beklioatiea (Abb. a) & $\begin{array}{l}-^{\prime}-{ }^{\prime}- \\
\text { 口od, }\end{array}$ & \multicolumn{2}{|c|}{ Aktive Lateralbeugung (Abb. b) } & $\begin{array}{l}-^{\prime}-{ }^{\prime}- \\
\text { 口‥B }\end{array}$ & \multicolumn{2}{|c|}{ Alctive Rotation (Abb.c) } & 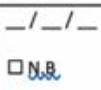 \\
\hline \multicolumn{8}{|l|}{ Funktion BWS / LWS } \\
\hline $\begin{array}{l}\text { Aktiv nach hinten beugen } \\
\text { (Extension) (Abb. d) }\end{array}$ & $\begin{array}{l}-^{\prime}-\prime- \\
\text { 口ouk }\end{array}$ & $\begin{array}{l}\text { Aktive Seitneigung (Abb. } \\
\text { f) }\end{array}$ & $\begin{array}{l}-^{\prime}-I- \\
\text { 口ㅅ․ }\end{array}$ & $\begin{array}{l}\text { Aktive } \\
\text { Oberkörperrotation } \\
\text { (Abb. g) }\end{array}$ & $\begin{array}{l}-^{\prime}-{ }^{\prime}- \\
\text { 매영 }\end{array}$ & $\begin{array}{l}\text { Aktiv } \\
\text { nach } \\
\text { vorne } \\
\text { beugen } \\
\text { (Abb. h) }\end{array}$ & $\begin{array}{l}-^{\prime}-{ }^{\prime}- \\
\text { 口uㅏ }\end{array}$ \\
\hline \multicolumn{8}{|l|}{ Test HWS } \\
\hline $\begin{array}{l}\text { Formen intervertebrale } \\
\text { Kompressions-Test }(\mathrm{Abb} .1 \mathrm{a}+\mathrm{b})\end{array}$ & 口Pos. und Schmerz decomatemberserea & \begin{tabular}{|l|} 
Pos. und Schmerz HWS \\
lokal
\end{tabular} & Q neg. & 口NkB & & & \\
\hline \multicolumn{8}{|l|}{ Tests BWS + LWS } \\
\hline Adams Test & $\square$ pos. (Rippenwulst/Lendenwulst) & Q neg. & वoks & & & & \\
\hline Proúfung von Fersenfallschmerz & Q pos. (Schmerz im Rücken) & a neg. & 口ok & & & & \\
\hline $\begin{array}{l}\text { Mod. aktives umgekehrtes } \\
\text { Lasegus'sches Zeichen (ohne } \\
\text { Untersucher) }\end{array}$ & $\begin{array}{l}\text { Q pos. (vermehrter Schmerz ventraler } \\
\text { os) }\end{array}$ & Qneg. & ads & & & & \\
\hline $\begin{array}{l}\text { Ubercoitte'sches Zeichen (ohne } \\
\text { Untersucher) }\end{array}$ & $\begin{array}{l}\text { pos. (vermehrter Schmerz Wirbelsāule } \\
\text { und obere oder untere Extc.) }\end{array}$ & Q neg. & 口ख⿱ & & & & \\
\hline $\begin{array}{l}\text { Mod. aktives Laserue'sches Zeichera } \\
\text { b (ohne Untersucher) }\end{array}$ & 口pos. & aneg. & 口ok & & & & \\
\hline
\end{tabular}

- Fig. 2 Systematic anamnestic questionaire and clinical findings. a Page 1. b Page 2. 


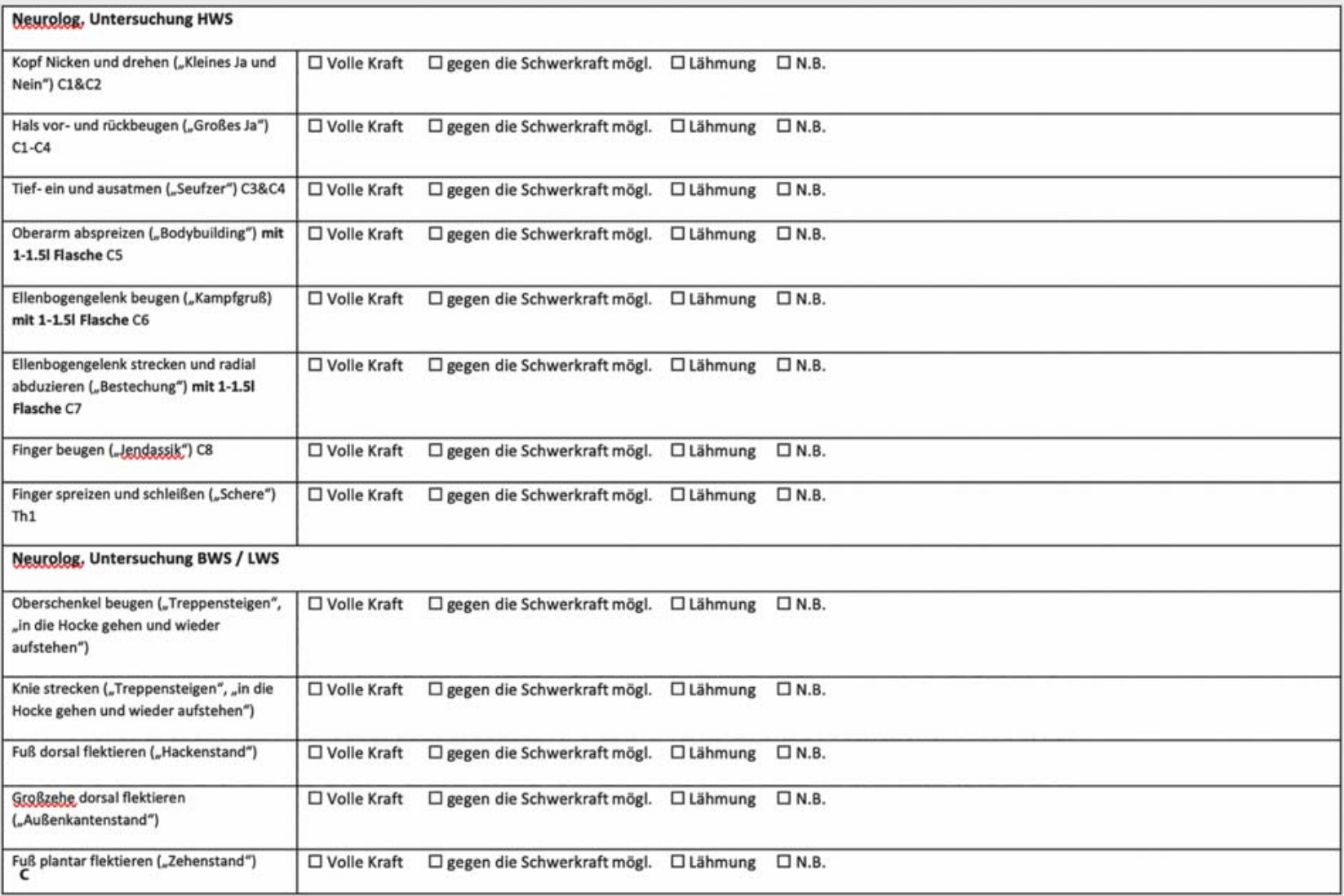

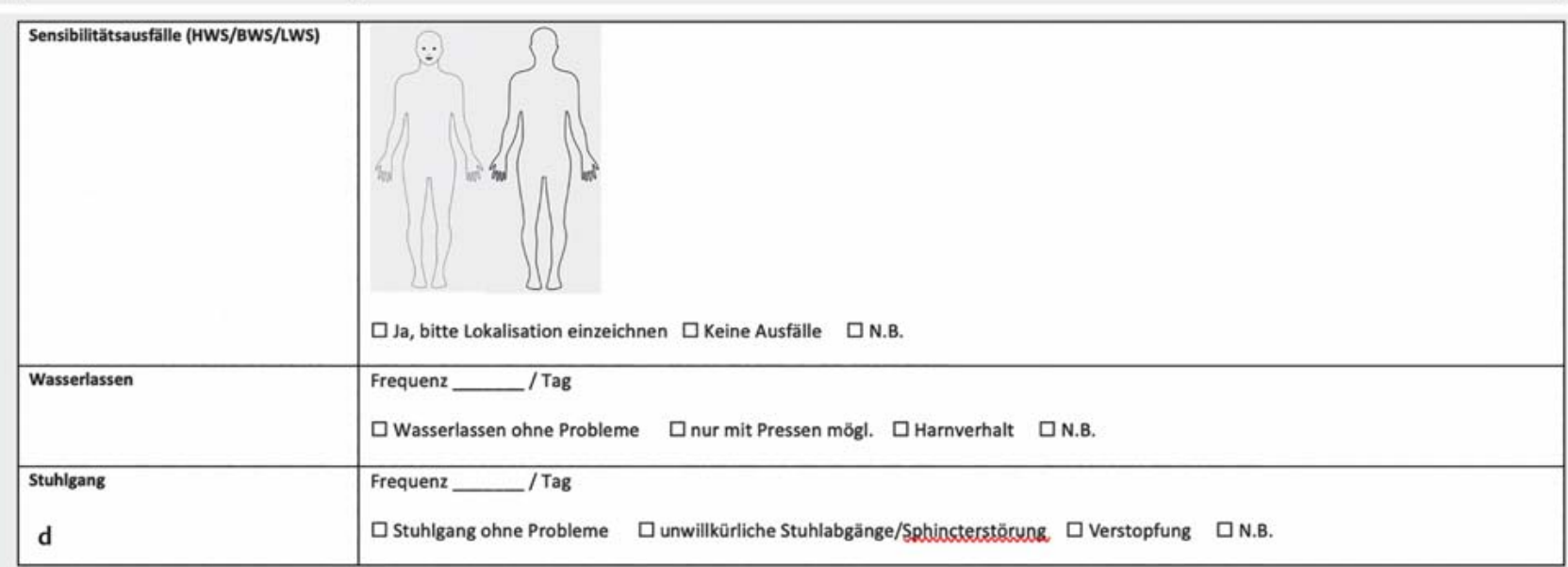

- Fig. 2 Systematic anamnestic questionaire and clinical findings (continued). c Page 3. d Page 4.

\section{Study population}

After giving informed consent, 43 patients were examined in our university hospital outpatient clinic.

The inclusion criteria were:

- Patient age over 18 years

- Referred by the specialist in orthopaedics and trauma surgery with spinal complaints

- Knowledge of German
- No cognitive deficits

- Written consent to take part in the study

\section{Statistical analysis}

Statistical analysis was performed with "R" version 4.0.0. Frequency distributions and the Cohen kappa test (in the corrected Brennan-Prediger version) to calculate the intra-rater reliability (IRR). The IRR was interpreted as follows, after Altman: 0 to 0.20 
- Table 1 Agreement of the test results.

\begin{tabular}{|c|c|c|c|c|c|}
\hline Category & Examination & Kappa & $\mathrm{Cl}$ & SE & $\mathbf{p}$ \\
\hline \multirow[t]{2}{*}{ Pain location } & NRS pain & 0.974 & $(0.923 ; 1.000)$ & 0.026 & $<0.0001$ \\
\hline & Pain location & 1.000 & $(1.000 ; 1.000)$ & 0.000 & $<0.0001$ \\
\hline \multirow[t]{5}{*}{ Inspection } & Dorsal inspection & 0.752 & $(0.592 ; 0.912)$ & 0.079 & $<0.0001$ \\
\hline & Gait & 0.944 & $(0.866 ; 1.000)$ & 0.039 & $<0.0001$ \\
\hline & Signs of infection & 0.930 & $(0.833 ; 1.000)$ & 0.048 & $<0.0001$ \\
\hline & Lateral inspection & 0.814 & $(0.672 ; 0.956)$ & 0.070 & $<0.0001$ \\
\hline & Wound inspection & 0.973 & $(0.919 ; 1.000)$ & 0.027 & $<0.0001$ \\
\hline \multirow{16}{*}{$\begin{array}{l}\text { Neurophysiological } \\
\text { examination }\end{array}$} & $\mathrm{Cl}$ and $\mathrm{CII}$ & 0.938 & $(0.852 ; 1.000)$ & 0.043 & $<0.0001$ \\
\hline & $\mathrm{Cl}-\mathrm{CIV}$ & 0.969 & $(0.907 ; 1.000)$ & 0.031 & $<0.0001$ \\
\hline & CIII and CIV & 0.969 & $(0.907 ; 1.000)$ & 0.031 & $<0.0001$ \\
\hline & $C V$ & 0.876 & $(0.757 ; 0.995)$ & 0.059 & $<0.0001$ \\
\hline & CVI & 0.907 & $(0.802 ; 1.000)$ & 0.052 & $<0.0001$ \\
\hline & C VII & 0.907 & $(0.802 ; 1.000)$ & 0.052 & $<0.0001$ \\
\hline & C VIII & 0.935 & $(0.844 ; 1.000)$ & 0.045 & $<0.0001$ \\
\hline & ThI & 0.907 & $(0.802 ; 1.000)$ & 0.052 & $<0.0001$ \\
\hline & Hip flexion & 0.659 & $(0.48 ; 0.838)$ & 0.089 & $<0.0001$ \\
\hline & Knee extension & 0.721 & $(0.554 ; 0.888)$ & 0.083 & $<0.0001$ \\
\hline & Dorsiflexion & 0.814 & $(0.672 ; 0.956)$ & 0.070 & $<0.0001$ \\
\hline & Great toe extension & 0.721 & $(0.554 ; 0.888)$ & 0.083 & $<0.0001$ \\
\hline & Plantarflexion & 0.721 & $(0.554 ; 0.888)$ & 0.083 & $<0.0001$ \\
\hline & Sensory deficits & 1.000 & $(1.000 ; 1.000)$ & 0.000 & $<0.0001$ \\
\hline & Urination frequency & 1.000 & $(1.000 ; 1.000)$ & 0.000 & $<0.0001$ \\
\hline & Defecation quality & 1.000 & $(1.000 ; 1.000)$ & 0.000 & $<0.0001$ \\
\hline \multirow[t]{6}{*}{ Provocation tests } & Adams test & 0.407 & $(0.181 ; 0.633)$ & 0.112 & 0.001 \\
\hline & Pain on heel strike & 0.860 & $(0.726 ; 0.995)$ & 0.066 & $<0,0001$ \\
\hline & $\begin{array}{l}\text { Cervical spine neuroforaminal compression } \\
\text { test }\end{array}$ & 0.938 & $(0.852 ; 1.000)$ & 0.043 & $<0.0001$ \\
\hline & Lasègue & 0.512 & $(0.295 ; 0.728)$ & 0.107 & $<0.0001$ \\
\hline & Reverse Lasègue & 0.407 & $(0.181 ; 0.633)$ & 0.112 & 0.001 \\
\hline & Lhermitte & 0.686 & $(0.498 ; 0.874)$ & 0.093 & $<0.0001$ \\
\hline
\end{tabular}

poor; $0.20-0.40$ low; $0.40-0.60$ moderate; $0.60-0.80$ good; $0.80-1.00$ very good [10].

\section{Informed consent and ethics committee approval}

Verbal and written consent was obtained from all study participants. The mental and physical integrity of the participants was respected and protected in accordance with the Declaration of Helsinki [11]. The study was examined and approved by the university's ethic committee (ethics application no. 163/20).

\section{Results}

43 patients in total ( 24 women and 19 men) were recruited for the study. The average age was about 60 years and the average body mass index was $28.6 \pm 6.2 \mathrm{~kg} / \mathrm{m}^{2}$ (18.6-38.5).

\section{Pain intensity and location}

The average pain intensity measured by numerical rating scale (NRS) [12] was 4.7 (SD \pm 2.3 ) in both examination with high IRR (kappa $=0.974)$. The majority of the patients suffered from pain of the lumbar spine (76.7\%). There was complete agreement regarding pain location between the results obtained by video consultation and those in the face-to-face examination (kappa $=1.00)$.

\section{Inspection}

There was very high agreement in the examination results between the video-based (VB) and direct face-to-face examination (FTF) in gait assessment (kappa $=0.944 ; \mathrm{Cl}=(0.866 ; 1.000)$; $\mathrm{p}<0.0001$ ), wound inspection ( $\mathrm{kappa}=0.973$; $\mathrm{Cl}=(0.919 ; 1.000)$; $\mathrm{p}=0.000000001)$ and lateral inspection (kappa $=0.814 ; \mathrm{Cl}=$ (0.672; 0.956); $\mathrm{p}<0.0001)$ ( $\triangleright$ Table 1). Posterior inspection 


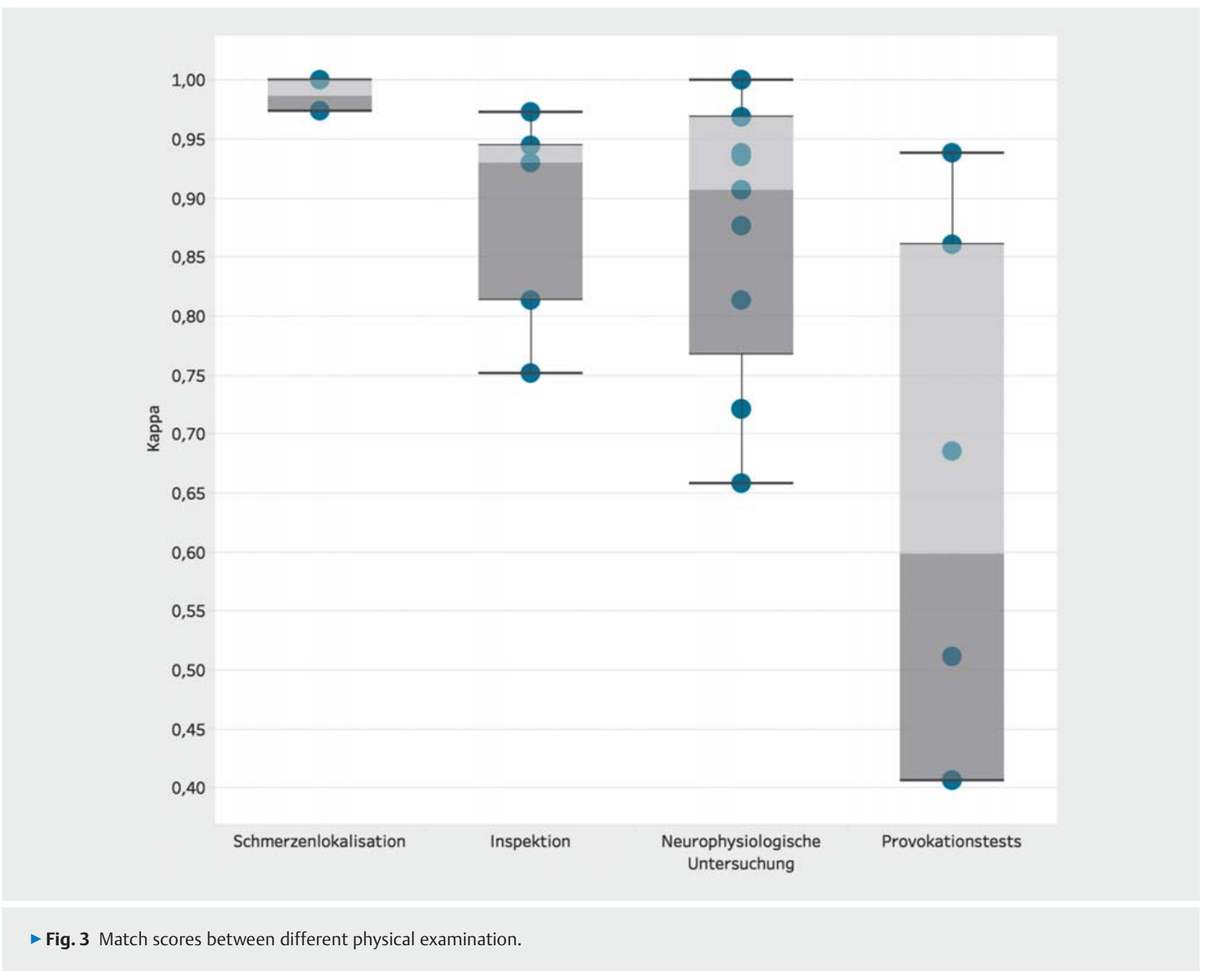

showed somewhat poorer agreement of the examination results between VB and FTF (kappa $=0.752 ; \quad \mathrm{Cl}=(0.592 ; 0.912)$; $\mathrm{p}<0.0001)$.

\section{Range of motion}

In the measurement of the AROM differences of $\pm 5^{\circ}$ were interpreted as method-related inaccuracies and accepted as equivalent [13]. There was good correlation between the two examinations.

\section{Basic neurophysiological examination}

When the results of the basic neurophysiological examination are considered, a distinction should be made between the upper and lower extremity. There was very good agreement overall between VB and FTF in the examination of the upper limb (kappa between 0.876 and 0.969 ). Examination of the lower limb yielded good agreement levels (kappa between 0.659 and 0.814).

\section{Provocation tests}

The provocation tests showed very varied but overall poorer agreement between VB and FTF. On the one hand, agreement was only moderate in the Lasègue test, reverse Lasègue test and Adams forward bend test. On the other hand, there was very good agreement for the cervical spine neuroforaminal compression test.

\section{General trends}

Agreement between the different dimensions of physical examination diminished in the following order: pain location, inspection, neurophysiological examination and provocation tests ( $\triangleright$ Fig.3). Moreover, an age-dependent decrease in agreement was measured across all dimensions ( $\triangleright$ Fig. 4).

\section{Discussion}

The rapid introduction and integration of telemedicine into orthopaedic and trauma surgery care is possible today due to the rapid advances in communication technology [14]. The technical re- 


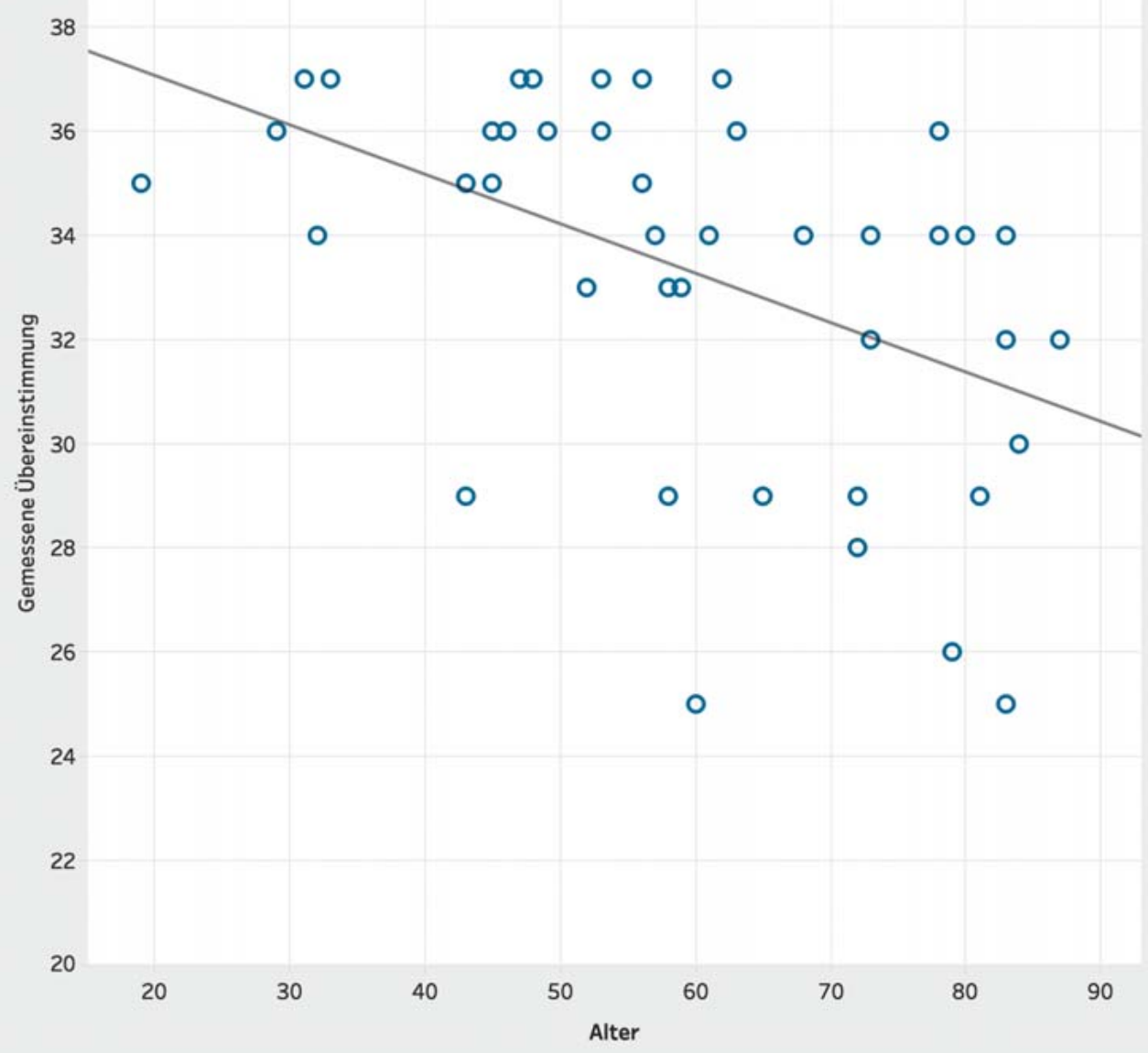

- Fig. 4 Age-dependent cross-dimensional agreement values.

quirements for setting up a video-based consultation are easy to meet and present almost everywhere in medical practices and hospitals [15]. Patients are open to telemedicine solutions [16] and are often just as satisfied with a video consultation as with a conventional outpatient treatment $[17,18]$.

Factors that can make physical examination via video consultation more difficult are low internet bandwidth [19], low camera resolution on the patient's side, poor lighting, excessive complexity of the tests performed [20] and poor videoconferencing etiquette [21]. Since palpation of the patient is not possible, a body diagram can be sent before the video examination in order to narrow down the pain [19]. Physical examination with palpation of, for example, muscle tension, tender points, instability tests or manual therapy tests such as the standing flexion test is likewise not possible.

The patient population with spinal complaints is very varied as regards age, socioeconomic status [22] and technical equipment. Some patients are therefore very suitable for video-based consultation, are comfortable with the technology and value the time efficiency and lack of travel time associated with video consultations $[23,24]$. Other patients have great difficulty in following and im- plementing the doctor's instructions by video. In our study, correct camera positioning by the patient in particular was a critical point in assessing the overall course of the examination. It is probably often difficult to evaluate gait disorders or clinical signs of myelopathy in a video consultation. With the majority of patients, however, it is possible to perform an inspection and examine AR$\mathrm{OM}$ and power during a video consultation [25]. Examination of muscle power had to be adapted to make it practically possible in a video consultation. Manual testing of muscle function according to Janda [26] with five levels is not possible in a video consultation without an examiner. We therefore simplified the measurement of power into three levels ("full power", "against gravity" and "paresis"). In addition, examination of the key muscles of the lower limb by video was often more difficult to assess than that of the upper limb. The provocation tests were difficult to impossible for a few patients. Elderly patients in particular had problems in our study in carrying out specific tests in the camera's field of view. The mortality rate due to COVID-19 is markedly increased precisely in the group of elderly and multimorbid patients and special infection prevention would be particularly important for this group of patients. Possible examination by video consultation 
would therefore be a useful addition to the conventional medical consultation especially for elderly patients. Assistance in carrying out a video consultation with elderly patients by relatives, friends or home carers could solve this dilemma but was not investigated in our study.

\section{Limitations}

This study has a range of limitations. The spinal examinations by video consultation were performed in a simulated setting in a hospital outpatient clinic. The technical equipment was provided for the patient on site. The intra-rater reliability was measured in two successive examinations. Because of this method, the examiner can still recall the previous examination during the second examination, so examiner bias is possible. The question of whether an examiner who is not familiar with carrying out a video consultation obtains the same results was not addressed. Furthermore, the study was conducted in a relatively small group of patients.

\section{Conclusion}

Our study shows the feasibility and limits of video-based spinal examination. Video consultations are a form of technology accepted by patients and readily usable for diagnostic investigation of back pain. Examination with direct face-to-face doctor-patient contact is and remains the gold standard. In the current COVID-19 pandemic, specialist consultation and spinal examination are possible by this means, without the risk of possible virus exposure. However, the quality and safety of using telemedicine for patients with back pain should be examined in further larger studies.

\section{Remarks}

The authors T. R. Jansen and M. Gathen contributed equally to this project and should be regarded as joint first authors. The authors K. Welle and K. Kabir contributed equally to this project and should be regarded as joint last authors. T. R. Jansen and K. Kabir are corresponding authors.

\section{Conflict of Interest}

The authors declare that they have no conflict of interest.

\section{References}

[1] Andersson GBJ. Epidemiological features of chronic low-back pain. The Lancet 1999; 354: 581-585. doi:10.1016/s0140-6736(99)01312-4

[2] James SL, Abate D, Abate KH et al. Global, regional, and national incidence, prevalence, and years lived with disability for 354 diseases and injuries for 195 countries and territories, 1990-2017: a systematic analysis for the Global Burden of Disease Study 2017. Lancet 2018; 392: 1789-1858. doi:10.1016/s0140-6736(18)32279-7

[3] Bundesärztekammer (BÄK), Kassenärztliche Bundesvereinigung (KBV), Arbeitsgemeinschaft der Wissenschaftlichen Medizinischen Fachgesellschaften (AWMF). Nationale VersorgungsLeitlinie Nicht-spezifischer Kreuzschmerz - Leitlinienreport. 2. Aufl. Version 1; 2017. doi:10.6101/ AZQ/000330
[4] [Anonym]. Ärzte appellieren, Arztbesuche nicht aufzuschieben. In: Deutsches Ärzteblatt. Online (last access: 15.05.2020): https://www. aerzteblatt.de/nachrichten/112413/Aerzte-appellieren-Arztbesuchenicht-aufzuschieben

[5] Grimes CL, Balk EM, Crisp CC et al. A guide for urogynecologic patient care utilizing telemedicine during the COVID-19 pandemic: review of existing evidence. Int Urogynecol J 2020. doi:10.1007/s00192-02004314-4

[6] Dorsey ER, Topol E]. State of Telehealth. N Engl ] Med 2016; 375: $154-$ 161. doi:10.1056/NEJMra1601705

[7] Lurie N, Carr BG. The Role of Telehealth in the Medical Response to Disasters. JAMA Intern Med 2018; 178: 745-746. doi:10.1001/jamainternmed. 2018.1314

[8] Smith AC, Thomas E, Snoswell CL et al. Telehealth for global emergencies: Implications for coronavirus disease 2019 (COVID-19). J Telemed Telecare 2020; 26: 309-313. doi:10.1177/1357633X20916567

[9] Tenforde AS, Hefner JE, Kodish-Wachs JE et al. Telehealth in Physical Medicine and Rehabilitation: A Narrative Review. PM R 2017; 9 (5S): S51-S58. doi:10.1016/j.pmrj.2017.02.013

[10] Altman DG. Practical Statistics for medical Research. Boca Raton, Florida, USA: CRC press; 1990

[11] Word Medical Association. World Medical Association Declaration of Helsinki: ethical principles for medical research involving human subjects. JAMA 2013; 310: 2191-2194. doi:10.1001/jama.2013.281053

[12] Holdgate A, Asha S, Craig J et al. Comparison of a verbal numeric rating scale with the visual analogue scale for the measurement of acute pain. Emerg Med (Fremantle) 2003; 15: 441-446

[13] van Trijffel E, van de Pol RJ, Oostendorp RA et al. Inter-rater reliability for measurement of passive physiological movements in lower extremity joints is generally low: a systematic review. J Physiother 2010; 56: 223235

[14] Behmanesh A, Sadoughi F, Mazhar FN et al. Tele-orthopaedics: A systematic mapping study. J Telemed Telecare 2020. doi:10.1177| $1357633 \times 20919308$

[15] Buvik A, Bugge E, Knutsen G et al. Patient reported outcomes with remote orthopaedic consultations by telemedicine: A randomised controlled trial. J Telemed Telecare 2019; 25: 451-459. doi:10.1177| $1357633 \times 18783921$

[16] Holderried M, Schlipf M, Hoper A et al. [Chances and Risks of Telemedicine in Orthopaedics and Trauma Surgery]. Z Orthop Unfall 2018; 156: 68-77. doi:10.1055/s-0043-116941

[17] Sharareh B, Schwarzkopf R. Effectiveness of telemedical applications in postoperative follow-up after total joint arthroplasty. J Arthroplasty 2014; 29: 918-922.e1. doi:10.1016/j.arth.2013.09.019

[18] Buvik A, Bugge E, Knutsen G et al. Quality of care for remote orthopaedic consultations using telemedicine: a randomised controlled trial. BMC Health Serv Res 2016; 16: 483. doi:10.1186/s12913-016-1717-7

[19] Lade H, McKenzie S, Steele L et al. Validity and reliability of the assessment and diagnosis of musculoskeletal elbow disorders using telerehabilitation. J Telemed Telecare 2012; 18: 413-418. doi:10.1258/jtt.2012. 120501

[20] Cabana F, Boissy P, Tousignant M et al. Interrater agreement between telerehabilitation and face-to-face clinical outcome measurements for total knee arthroplasty. Telemed J E Health 2010; 16: 293-298. doi:10.1089/tmj.2009.0106

[21] Russell T, Truter P, Blumke R et al. The diagnostic accuracy of telerehabilitation for nonarticular lower-limb musculoskeletal disorders. Telemed ] E Health 2010; 16: 585-594. doi:10.1089/tmj.2009.0163

[22] Hestbaek L, Korsholm L, Leboeuf-Yde C et al. Does socioeconomic status in adolescence predict low back pain in adulthood? A repeated crosssectional study of 4,771 Danish adolescents. Eur Spine J 2008; 17: 1727-1734. doi:10.1007/s00586-008-0796-5 
[23] Thompson JC, Cichowski SB, Rogers RG et al. Outpatient visits versus telephone interviews for postoperative care: a randomized controlled trial. Int Urogynecol J 2019; 30: 1639-1646. doi:10.1007/s00192-01903895-z

[24] Buvik A, Bergmo TS, Bugge E et al. Cost-Effectiveness of Telemedicine in Remote Orthopedic Consultations: Randomized Controlled Trial. J Med Internet Res 2019; 21: e11330. doi:10.2196/11330
[25] Mani S, Sharma S, Singh DK. Concurrent validity and reliability of telerehabilitation-based physiotherapy assessment of cervical spine in adults with non-specific neck pain. J Telemed Telecare 2019. doi:10.1177/ $1357633 \times 19861802$

[26] Janda V. Muscle Function Testing. Amsterdam: Elsevier; 2013 